\title{
Polyboration Reaction of 1,1-Diethynyl-1-silacyclopent-3-ene with Boranes
}

\author{
Myung Hwa Kim and Young Tae Park* \\ Department of Chemistry, Keimyung University, Daegu 704-701, Korea. *E-mail: ytpark@kmu.ac.kr \\ Received October 29, 2004
}

Key Words : Polycarbosilane, Polyboration, Silacyclopent-3-ene, Boranes, Electronic and thermal properties

\begin{abstract}
Conjugated polycarbosilanes through polymer backbone have received much attention for their potential applications as electronic and ceramic materials. ${ }^{1}$ In this sense, considerable research efforts have been devoted to develop new polycarbosilanes containing novel conjugation moieties. Poly[(silylene)diacetylene] polymers showed conductivity values in the range of $10^{-5} \sim 10^{-3} \mathrm{~S} / \mathrm{cm}$ when doped with $\mathrm{FeCl}_{3}$, and pyrolysis of the polycarbosilanes in inert atmosphere resulted in a $\beta$-SiC ceramic materials in high yield. ${ }^{2}$ Conjugated poycarbosilanes bearing arylethylene or acetylene-linked dithienosilole have been prepared and their electronic properties were also reported. ${ }^{3}$ Oligomeric materials composed of alternating 2,5-bis(ethynylenedimethylsilylene)thienylene and arylene units in the main chain have been prepared by a cross-coupling reaction. ${ }^{4}$ We have also reported the preparation and excited-state energy dynamics of polycarbosilanes containing 1,4-bis(thiophene or phenylene)buta-1,3-diyne in the polymer backbone. ${ }^{5}$ Organosilacyclic compounds such as 1-silacyclopent-3-enes have received much concern in organosilicon chemistry. ${ }^{6} 1,1$ Dimethyl-1-silacyclopent-3-ene undergoes anionic ringopening reaction to give poly(1,1-dimethyl-1-sila-cis-pent3 -ene). ${ }^{7}$ Recently, we reported the preparation of polycarbosilanes containing diacetylenic and organosilacyclic groups along the polymer main chain such as poly(1,1-diethynyl-1silacyclopent-3-enes and 1,1-diethynyl-1-silacyclobutane) using oxidative coupling polymerization and their electronic properties. $^{8}$ Organoborons are useful reagents for the preparation of a variety of functional compounds in organic synthesis. ${ }^{9}$ Chujo et al. have reported that various $\pi$ conjugated organoboron polymers consisting of C-B bonds in the main chain were able to be synthesized by several polyaddition reactions between organic diynes and borane derivatives. $^{10}$
\end{abstract}

However, boration polymerizations between organosilicon diynes and borane derivatives have been scarcely reported. Very recently, we have demonstrated the boration polymerizations between 1,1-diethynyl-3-triethylsilyl-1-silacyclopent3-ene and several borane derivatives. ${ }^{11}$ Since we have successfully prepared 1,1-diethynyl-1-silacyclopent-3-ene as novel diyne-containing silacyclic monomer, ${ }^{8,12}$ we have decided to extend this polyaddition technique to the preparation of polycarbosilanes containing silacyclopentene and organoboron groups along the polymer backbone by utilizing 1,1-diethynyl-1-silacyclopent-3-ene. Furthermore, the synthesized organoborane-bearing polycarbosilanes can be expected to include a novel $\pi$-conjugated moiety of $\mathrm{C}=\mathrm{C}$ $\mathrm{B}-\mathrm{C}=\mathrm{C}$ and the organosilacyclic group of silacyclopent-3ene along the polymer main chains. Here, we now report the polyboration reaction of 1,1-diethynyl-1-silacyclopent-3-ene with several organoborane derivatives along with the electronic and thermal properties of the obtained carbosilane materials. In particular, the fluorescence emission maxima of the prepared oligomers containing 1-silacyclopent-3-enes and boranes were observed at the range of $310-415 \mathrm{~nm}$, whereas $\pi$-conjugated organoboron polymers containing heteroaromatic monomer such as thiophene or pyridine and mesitylborane showed those emission maxima at the visible region of $416-593 \mathrm{~nm}^{11,13}$

\section{Results and Discussion}

Synthesis of Oligomers. 1,1-Diethynyl-1-silacyclopent3-ene (1) was synthesized by the reaction of 1,1-dichloro-1silacyclopent-3-ene with ethynylmagnesium chloride according to the previous method reported by our research group. ${ }^{8}$ The monomer 1 was characterized using several spectroscopic methods such as ${ }^{1} \mathrm{H},{ }^{13} \mathrm{C}$, and ${ }^{29} \mathrm{Si} \mathrm{NMR}$ as well as IR spectroscopy. In the IR spectrum of $\mathbf{1}$, the characteristic acetylenic $\mathrm{C} \equiv \mathrm{C}$ and ring vinyl $\mathrm{C}=\mathrm{C}$ stretching frequencies are observed at 2040 and $1606 \mathrm{~cm}^{-1}$, respectively. In the ${ }^{1} \mathrm{H}$ NMR spectrum of $\mathbf{1}$, the singlet resonance appears at 2.56 ppm for ethynyl $(\mathrm{C} \equiv \mathrm{CH})$ protons and the triplet at $5.91 \mathrm{ppm}$ for vinyl $(\mathrm{C}=\mathrm{CH})$ proton on the ring. In the ${ }^{13} \mathrm{C} N M R$ spectrum of $\mathbf{1}$, four carbon peaks appear at 18.11, 84.12, 96.26 , and $130.14 \mathrm{ppm}$, where the resonances assigned to the ethynyl carbons are observed at 84.12 and $96.26 \mathrm{ppm}$, and one assigned to the vinyl carbons at $130.14 \mathrm{ppm}$. In the ${ }^{29} \mathrm{Si}$ NMR spectrum of $\mathbf{1}$, silicon peak appears at -29.78 ppm.

The polyaddition reactions of $\mathbf{1}$ with several borane derivatives $\mathbf{2 a - e}$ were carried out to give the novel materials 3a-e in moderate yields, respectively, which contain $\mathrm{C}=\mathrm{C}-\mathrm{B}-$ $\mathrm{C}=\mathrm{C}$ moiety and organosilacyclic group in the polymer main chain, as shown in Scheme 1. These boration reactions proceed selectively in the manner of cis addition. ${ }^{10 a, 14}$

The boron-bearing polycarbosilanes 3a-e obtained as dark brown powder or yellowish viscous gel were found to be soluble in common organic solvents such as $\mathrm{CHCl}_{3}$ and THF. By running gel permeation chromatography (GPC) we measured average molecular weights of 3a-e which turned out to be oligomers with average molecular weights ranging 
<smiles>C#C[Si]1(C#C)CC=CC1</smiles>

1

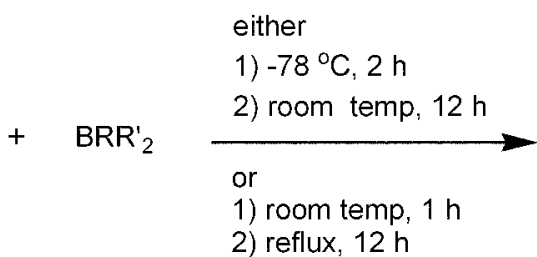

2a: $\mathrm{R}, \mathrm{R}^{\prime}=\mathrm{Br}$

$2 b: R, R^{\prime}=C l$

$2 \mathrm{c}: \mathrm{R}, \mathrm{R}^{\prime}=n-\mathrm{Bu}$

2d : $\mathrm{R}=\mathrm{Ph}, \mathrm{R}^{\prime}=\mathrm{Cl}$

$2 \mathrm{e}: \mathrm{R}=n-\mathrm{Bu}, \mathrm{R}^{\prime}=\mathrm{Cl}$

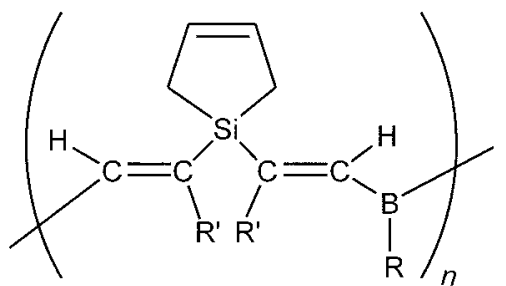

3a $: \mathrm{R}, \mathrm{R}^{\prime}=\mathrm{Br}(59 \%)$

3b : R, R' $=\mathrm{Cl}(94 \%)$

$3 \mathrm{c}: \mathrm{R}, \mathrm{R}^{\prime}=n-\mathrm{Bu}(76 \%)$

3d : R $=\mathrm{Ph}, \mathrm{R}^{\prime}=\mathrm{Cl}(99 \%)$

$3 \mathrm{e}: \mathrm{R}=n-\mathrm{Bu}, \mathrm{R}^{\prime}=\mathrm{Cl}(63 \%)$

Scheme 1

$1,820 / 1,370-13,410 / 7,480 \quad\left(M_{w} / M_{n}\right)$ and to have broad molecular weight distributions with the polydispersity indexes of 1.18-3.50, as summerized in Table 1. The broad molecular weights distributions might be attributed to the copolymerization technique applied in this research by using the two different types of monomers. ${ }^{15}$

The structures of 3a-e were confirmed by ${ }^{1} \mathrm{H},{ }^{13} \mathrm{C},{ }^{29} \mathrm{Si},{ }^{11} \mathrm{~B}$ NMR, and IR spectra along with elemental analysis. Some selected spectral properties of the oligomers 3a-e are outlined in Table 1.

In the FTIR spectra of all the oligomers 3a-e, the characteristic $\mathrm{C} \equiv \mathrm{C}$ stretching frequency of $\mathbf{1}$ at $2040 \mathrm{~cm}^{-1}$ almost disappeared and the $\mathrm{C}=\mathrm{C}$ stretching frequencies in the silacyclopentene ring of $\mathbf{1}$ remained intact at 1602-1611 $\mathrm{cm}^{-1}$, while the new strong $\mathrm{C}=\mathrm{C}$ stretching frequencies appeared at $1692-1714 \mathrm{~cm}^{-1}$, which indicates that the $\mathrm{C}=\mathrm{C}$ bonds along the oligomer backbones were newly formed during polyaddition reactions. ${ }^{16}$

In the ${ }^{1} \mathrm{H}$ NMR spectra of 3a-e, the ethynyl protons of $\mathbf{1}$ at $2.56 \mathrm{ppm}$ disappeared and the vinyl proton on the silacyclopentene ring of 1 remained intact at 5.61-5.94 ppm, while the new vinyl protons appeared at 4.62-5.04 ppm, which suggests that the structures of oligomers 3a-e are consistent with the proposed ones as shown in Scheme 1. The ${ }^{13} \mathrm{C}$ NMR of 3a-e show that the ethynyl $\mathrm{C} \equiv \mathrm{C}$ carbon resonances of 1 at 84.12 and 96.26 ppm disappeared and the vinyl $\mathrm{C}=\mathrm{C}$ carbon peaks in the silacyclopentene ring of $\mathbf{1}$ remained intact at $130.56-132.80 \mathrm{ppm}$, while the new vinyl $\mathrm{C}=\mathrm{C}$ carbon resonances appeared at 128.00-130.92 ppm, which is also consistent with the proposed structure of oligomers 3a-e. The structures of oligomers 3a-e were also confirmed by the ${ }^{29} \mathrm{Si}$ and ${ }^{11} \mathrm{~B}$ NMR spectra of all the prepared oligomers, as shown in Table 1 . In the case of the polyadditions of dichlophenylborane (2d) and dichlorobutylborane (2e), haloboration reactions occurred to yield the corresponding oligomers $\mathbf{3 d}$ and $\mathbf{3 e}$, respectively, due to the higher reactivity of halogen atom such as chlorine than that of phenyl or butyl groups. ${ }^{17}$

Properties of Oligomers. All the oligomers 3a-e were found to be soluble in common organic solvents of THF and chloroform. The solubility of 3a-e permits us to perform studies on the properties in solution. In the UV-vis spectra of oligomers 3a-e, the strong absorption bands are observed at the $\lambda_{\max }$ of 254-291 nm, as listed in Table 1, which are probably attributed to the presence of $\mathrm{C}=\mathrm{C}-\mathrm{B}-\mathrm{C}=\mathrm{C}$ chromophore along the oligomer backbone. ${ }^{18}$ The UV-vis absorption maxima of polymer 3a-e were not much different in comparison with the $\lambda_{\max }$ of $268-275 \mathrm{~nm}$ of the oligomers containing 3-triethylsilyl-1-silacyclopent-3-ene and boranes. ${ }^{11}$

The typical excitation spectrum for $\mathbf{3 e}$ at the detection wavelength of $339 \mathrm{~nm}$ in THF exhibits the strong excitation band at the $\lambda_{\max }$ of $287 \mathrm{~nm}$, as shown in Figure 1. As outlined in Table 1, the excitation spectra of 3a-d at the detection wavelengths of $300-410 \mathrm{~nm}$ in THF show that the strong excitation peaks appear at the $\lambda_{\max }$ of $273-334 \mathrm{~nm}$, which are probably attributable to $\mathrm{C}=\mathrm{C}-\mathrm{B}-\mathrm{C}=\mathrm{C}$ group along the oligomer chain. The excitation maxima of polymer 3a-e were observed at longer wavelengths in comparison with

Table 1. Selected Properties of the Oligomers 3a-e

\begin{tabular}{|c|c|c|c|c|c|c|c|c|}
\hline Oligomer & $M_{w}, \mathrm{PDI}^{a}$ & $\begin{array}{c}{ }^{29} \mathrm{Si} \mathrm{NMR}^{b} \\
\delta \text { (ppm) }\end{array}$ & $\begin{array}{l}{ }^{11} \mathrm{~B} \mathrm{NMR}^{b} \\
\delta(\mathrm{ppm})\end{array}$ & $\begin{array}{c}\mathrm{IR}^{c} \\
v_{(\mathrm{C}=\mathrm{C})}\left(\mathrm{cm}^{-1}\right)\end{array}$ & $\begin{array}{c}\text { Absorption }^{d} \\
\lambda_{\max }(\mathrm{nm})\end{array}$ & $\begin{array}{c}\text { Excitation }^{e} \\
\lambda_{\max }(\mathrm{nm})\end{array}$ & $\begin{array}{c}\text { Fluorescence }^{f} \\
\lambda_{\max }(\mathrm{nm})\end{array}$ & $\mathrm{TGA}^{g}$ \\
\hline $3 a$ & $1820,1.32$ & -33.86 & -2.56 & 1714 & 268 & 273 & 330 & 59 \\
\hline $3 \mathbf{b}$ & $7970,3.50$ & -17.23 & -2.00 & 1699 & 274 & 334 & 415 & 82 \\
\hline $3 c$ & $13410,1.79$ & -21.93 & -0.82 & 1699 & 291 & 321 & 390 & 92 \\
\hline 3d & $4050,1.18$ & -14.70 & -1.24 & 1692 & 254 & 285 & 346 & 78 \\
\hline $3 e$ & $13430,2.45$ & -15.75 & -2.25 & 1702 & 269 & 287 & 336 & 70 \\
\hline
\end{tabular}

${ }^{a}$ Determined by GPC in THF relative to polystyrene standards. $M_{w} / M_{n}=$ Polydispersity index (PDI). ${ }^{b}$ Taken in $\mathrm{CDCl}_{3 .}{ }^{c} \mathrm{C}=\mathrm{C}$ bond stretching in the oligomer main chain and measured by neat or DRIFT method. ${ }^{d} \mathrm{UV}$-vis absorption in THF. ${ }^{e}$ Detection wavelengths at $300-410 \mathrm{~nm}$ in THF. ${ }^{f}$ Excitation wavelengths at $280-340 \mathrm{~nm}$ in THF. ${ }^{\circ} \%$ Weight remaining at $400{ }^{\circ} \mathrm{C}$ under nitrogen. 


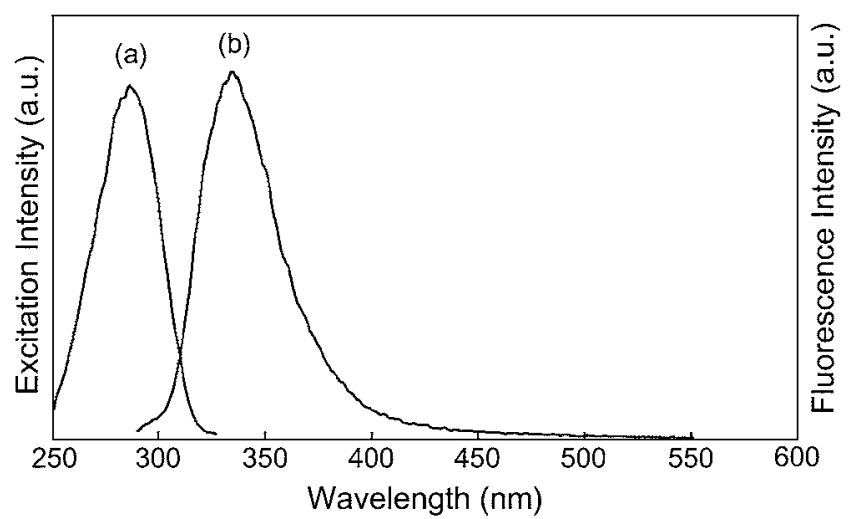

Figure 1. Excitation (line (a), $\lambda_{\operatorname{det}}=339 \mathrm{~nm}$ ) and fluorescence (line (b), $\lambda_{\mathrm{ex}}=285 \mathrm{~nm}$ ) spectra of the oligomer $3 \mathbf{e}$ in THF.

those of 255-279 $\mathrm{nm}$ of the oligomers containing 3triethylsilyl-1-silacyclopent-3-ene and boranes. ${ }^{11}$

The typical fluorescence emission spectrum of $\mathbf{3 e}$ at the excitation wavelength of $285 \mathrm{~nm}$ exhibits the strong emission peak at the $\lambda_{\max }$ of $336 \mathrm{~nm}$ with the broad emission band of 300-520 nm, as shown in Figure 1. As indicated in Table 1, the fluorescence emission spectra of 3a-d at the excitation wavelengths of 280-340 nm in THF reveal that the strong fluorescence emission peaks appear at the $\lambda_{\max }$ of $330-415 \mathrm{~nm}$, which are probably ascribed to the fluorophore of $\mathrm{C}=\mathrm{C}-\mathrm{B}-\mathrm{C}=\mathrm{C}$ along the oligomer chain. ${ }^{18}$ The emission maxima of polymer 3a-e were observed relatively at longer wavelengths as compared with those of 310-370 nm of the oligomers containing 3-triethylsilyl-1-silacyclopent-3-ene and boranes. ${ }^{11}$

Those strong absorption, excitation, and fluorescence bands of 3a-e in their corresponding spectra imply that all the prepared oligomers contain the partially delocalized $\pi$ conjugation groups of $\mathrm{C}=\mathrm{C}-\mathrm{B}-\mathrm{C}=\mathrm{C}$ as well as organosilacyclic moiety through the oligomer main chains.

The thermal stabilities of oligomers 3a-e under nitrogen atmosphere were examined by thermogravimetric analysis (TGA) with a program heating rate of $10^{\circ} \mathrm{C} / \mathrm{min}$. The typical TGA thermogram of $\mathbf{3 c}$ was shown in Figure 2. 3c is stable up to $200{ }^{\circ} \mathrm{C}$ with weight loss of $1 \%$ only. Rapid weight loss of $38 \%$ of the initial weight occurs between 300 and $600{ }^{\circ} \mathrm{C}$. When $3 \mathbf{c}$ is heated to $900{ }^{\circ} \mathrm{C}, 48 \%$ of the initial weight of $\mathbf{3 c}$ is lost, and about $52 \%$ of TGA char yield is observed.

Normally, the oligomers 3a-e are thermally stable up to $182-200{ }^{\circ} \mathrm{C}$ with weight loss of $1-10 \%$ only. Rapid weight loss of $18-38 \%$ of the initial weight occurs between 300 and $600{ }^{\circ} \mathrm{C}$. When the oligomers are heated to $900{ }^{\circ} \mathrm{C}$ by the heating rate of $10{ }^{\circ} \mathrm{C} / \mathrm{min}$, residues of $23-59 \%$ remain. Usually, about $59-92 \%$ of the initial polymer weights remain at $400{ }^{\circ} \mathrm{C}$ under nitrogen atmosphere, as indicated in Table 1.

In conclusion, we have successfully prepared the oligomeric carbosilane materials which contain the partially delocalized $\pi$-conjugation moiety of $\mathrm{C}=\mathrm{C}-\mathrm{B}-\mathrm{C}=\mathrm{C}$ as well as organosilacyclic group along the oligomer main chains by the polyaddition reaction of 1,1-diethynyl-1-silacyclopent-3ene with several organoborane derivatives.

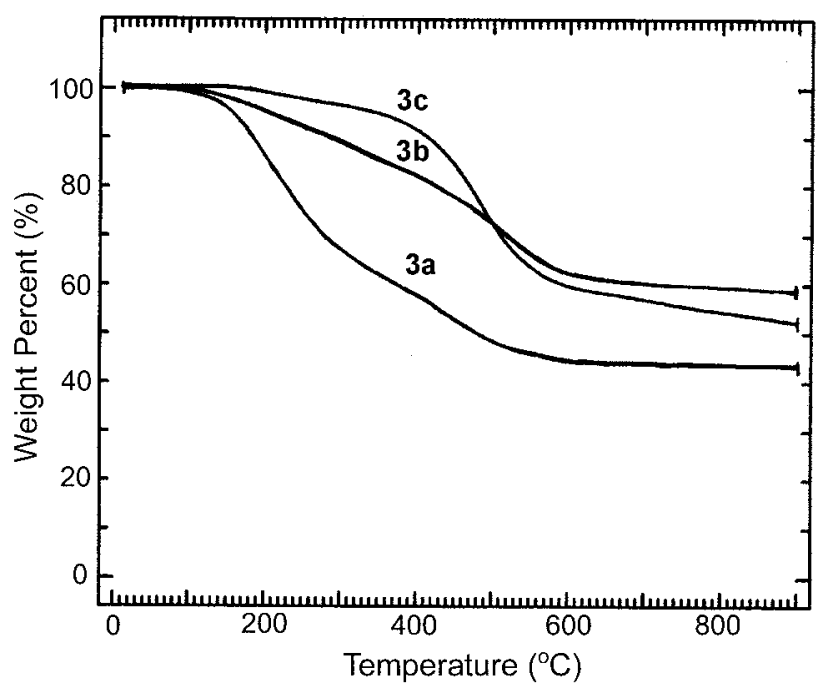

Figure 2. TGA thermogram of the oligomers $\mathbf{3 a}, \mathbf{3 b}$, and $\mathbf{3 c}$ under nitrogen.

\section{Experimental Section}

General Procedures. All chemicals were purchased from Aldrich Chemicals Inc. All solvents were purified prior to use according to standard literature methods. ${ }^{19}$ All glasswares were assembled and then flame-dried while being swept with dry argon. Reactions were monitored by Hewlett Packard 5890II analytical GLC equipped with HP-1 capillary column $(0.53 \mathrm{~mm} \times 30 \mathrm{~m})$ coated with cross-linked methyl silicon gum and with flame ionization detector (FID). ${ }^{1} \mathrm{H}$ (operating at $400 \mathrm{MHz}$ ) and ${ }^{13} \mathrm{C}$ (operating at 100 $\mathrm{MHz}$ ) nuclear magnetic resonance (NMR) spectroscopy were performed on a Bruker DRX Avance $400 \mathrm{MHz}$ FTNMR spectrometer using $\mathrm{CDCl}_{3}$ as solvent. Chemical shifts were measured using tetramethylsilane as internal standard or the residual proton signal of the solvent as standard. ${ }^{29} \mathrm{Si}$ (operating at $99 \mathrm{MHz}$ ) and ${ }^{11} \mathrm{~B}$ (operating at $160 \mathrm{MHz}$ ) NMR spectroscopy were performed on a Varian Unity INOVA $500 \mathrm{MHz}$ FT-NMR spectrometer at the Korea Basic Science Institute. IR spectra were recorded by a Bruker IFS48 FT-IR spectrometer using DRIFT method. UV-vis absorption spectra were obtained on a Hewlett Packard 8453 spectrophotometer. Excitation and fluorescence emission spectra were obtained on a Hitachi F-4500 fluorescence spectrophotometer. Gel permeation chromatography (GPC) analyses were performed on a Waters 1525 pump and Breeze software system with a Waters Styragel HR 3 column and refractive index detector at $40{ }^{\circ} \mathrm{C}$. The eluent was THF at a flow rate of $1.0 \mathrm{~mL} / \mathrm{min}$. The calibration was made with a series of monodispersed polystyrene standards: $M_{\mathrm{p}} 580,3250,10100$, and 28500 whose $M_{\mathrm{w}} / M_{\mathrm{n}}$ are less than 1.2. Thermogravimetric analysis (TGA) of polymer samples was performed on a TGA-50 Shimadzu thermal analysis system. The temperature was increased at a heating rate of $10{ }^{\circ} \mathrm{C} / \mathrm{min}$ from room temperature to $900{ }^{\circ} \mathrm{C}$ with a nitrogen flow rate of $20 \mathrm{~mL} / \mathrm{min}$. Elemental analyses were performed on a Fisons EA 1108 elemental analyzer. 
1,1-Diethynyl-1-silacyclopent-3-ene (1) was prepared by the previously reported method. ${ }^{8,12}$

Polyboration Reactions of 1 with Borane Derivatives (2). A general procedure for polyaddition reactions of $\mathbf{1}$ with 2 is described as follows: In a flame dried $50 \mathrm{~mL}$ Schlenk flask with rubber septum, boron tribromide $(\mathbf{2 a})(1.0 \mathrm{M} /$ dichloromethane, $7.58 \mathrm{~mL}, 7.58 \mathrm{mmol}$ ) was placed using a syringe under argon atmosphere. The flask was cooled to $-78{ }^{\circ} \mathrm{C}$ using a dry ice/acetone bath, and then $\mathbf{1}$ (1.00 g, 7.58 mmol) was added with vigorous stirring. The reaction mixture was stirred for $2 \mathrm{hrs}$ and allowed to warm to room temperature with well stirring for overnight. The crude oligomer was precipitated by addition of dry $n$-pentane or methanol and dried under reduced pressure. The oligomeric material 3a, $1.71 \mathrm{~g}, 59 \%$ was obtained as a dark brown solid with $M_{w} / M_{n}$ of $1,820 / 1,370$ (polydispersity index, PDI = 1.32). ${ }^{1} \mathrm{H}$ NMR (DMSO- $d_{6}, 400 \mathrm{MHz}$ ): $\delta 1.79$ (m, 4H), 4.62 (br s, 2H), $5.61(\mathrm{~m}, 2 \mathrm{H}) ;{ }^{13} \mathrm{C} \mathrm{NMR}\left(\mathrm{CDCl}_{3}, 100 \mathrm{MHz}\right): \delta$ $17.50,128.44,129.72,130.56 ;{ }^{29} \mathrm{Si} \mathrm{NMR}\left(\mathrm{CDCl}_{3}, 99 \mathrm{MHz}\right)$ : $\delta-33.86 ;{ }^{11} \mathrm{~B}$ NMR $\left(\mathrm{CDCl}_{3}, 160 \mathrm{MHz}\right): \delta-2.56$; IR $(\mathrm{KBr}$, DRIFTS): $v 3212,3059,2956,2041(\mathrm{w}), 1714(\mathrm{C}=\mathrm{C}), 1611$, 1434, 1196, 1073, $809 \mathrm{~cm}^{-1}$; UV-vis (THF): $\lambda_{\max } \mathrm{nm}(\varepsilon) 268$ $\left(3.36 \times 10^{3}\right)$. Anal. Calcd for $\left(\mathrm{C}_{8} \mathrm{H}_{8} \mathrm{SiBBr}_{3}\right)_{n}: \mathrm{C}, 25.10 ; \mathrm{H}$, 2.11. Found: $\mathrm{C}, 24.84 ; \mathrm{H}, 2.10$. All the excitation and fluorescence emission spectra in THF solution as well as TGA thermogram are described in Result and Discussion.

A dark brown solid $\mathbf{3 b}(1.77 \mathrm{~g}, 94 \%)$ was obtained from $\mathbf{1}$ $(1.00 \mathrm{~g}, 7.58 \mathrm{mmol})$ and boron trichloride $(\mathbf{2 b})(1.0 \mathrm{M} /$ dichloromethane, $7.58 \mathrm{~mL}, 7.58 \mathrm{mmol}): M_{w} / M_{n}=7,970 /$ 2,270 (PDI = 3.50); ${ }^{1} \mathrm{H} \mathrm{NMR}\left(\mathrm{CDCl}_{3}, 400 \mathrm{MHz}\right): \delta 1.55(\mathrm{~m}$, $4 \mathrm{H}), 4.85$ (br s, $2 \mathrm{H}), 5.94(\mathrm{~m}, 2 \mathrm{H}) ;{ }^{13} \mathrm{C} \mathrm{NMR}\left(\mathrm{CDCl}_{3}, 100\right.$ $\mathrm{MHz}): \delta 20.41,128.93,130.92,132.15 ;{ }^{29} \mathrm{Si} \mathrm{NMR}\left(\mathrm{CDCl}_{3}\right.$, $99 \mathrm{MHz}): \delta-17.23 ;{ }^{11} \mathrm{~B} \mathrm{NMR}\left(\mathrm{CDCl}_{3}, 160 \mathrm{MHz}\right): \delta-2.00$; IR (KBr, DRIFTS): $v$ 3213, 3038, 2962, 2042 (w), 1699 $(\mathrm{C}=\mathrm{C}), 1606,1457,1196,1044,808 \mathrm{~cm}^{-1}$; UV-vis (THF): $\lambda_{\max } \mathrm{nm}(\mathrm{e}) 274\left(1.02 \times 10^{4}\right)$. Anal. Calcd for $\left(\mathrm{C}_{8} \mathrm{H}_{8} \mathrm{SiBCl}_{3}\right)_{n}$ : C, 38.53; H, 3.23. Found: C, 37.87; H, 3.13.

A reddish yellow viscous gel $\mathbf{3 c}(1.80 \mathrm{~g}, 76 \%)$ was obtained from 1 (1.00 g, $7.58 \mathrm{mmol}$ ) and tributylborane (2c) (1.0 M/diethyl ether, $7.58 \mathrm{~mL}, 7.58 \mathrm{mmol})$. The reaction mixture was stirred at room temperature for $1 \mathrm{~h}$ and then warmed to reflux for overnight. For oligomer 3c: $M_{w} / M_{n}=$ $13,410 / 7,480$ (PDI = 1.79); ${ }^{1} \mathrm{H} \mathrm{NMR}\left(\mathrm{CDCl}_{3}, 400 \mathrm{MHz}\right): \delta$ 0.92-0.97 (m, 9H), 1.23-1.70 (br m, 18H), 1.87 (m, 4H), 4.94 (br s, 2H), 5.94 (m, 2H); ${ }^{13} \mathrm{C} \mathrm{NMR}\left(\mathrm{CDCl}_{3}, 100 \mathrm{MHz}\right)$ : $\delta 13.63,13.84,18.86,19.02,22.60,26.73,29.70,30.49$, $34.80,128.58,130.44,131.56 ;{ }^{29} \mathrm{Si} \mathrm{NMR}\left(\mathrm{CDCl}_{3}, 99 \mathrm{MHz}\right)$ : $\delta-21.93 ;{ }^{11} \mathrm{~B}$ NMR $\left(\mathrm{CDCl}_{3}, 160 \mathrm{MHz}\right): \delta-0.82$; IR (neat): v 3015, 2959, 2929, 2871, 2035 (w), 1699 (C=C), 1607, 1559, 1457, 1377, 1326, 1262, 1098, 1021, $802 \mathrm{~cm}^{-1}$; UVvis $(\mathrm{THF}): \lambda_{\max } \mathrm{nm}(\varepsilon) 291\left(1.54 \times 10^{4}\right)$. Anal. Calcd for $\left(\mathrm{C}_{20} \mathrm{H}_{35} \mathrm{SiB}\right)_{n}$ : C, $76.41 ; \mathrm{H}, 11.22$. Found: $\mathrm{C}, 75.72 ; \mathrm{H}, 11.16$.

A dark brown powder 3d (2.2 g, 99\%) was obtained from 1 (1.00 g, $7.58 \mathrm{mmol})$ and dichlorophenylborane (2d) (0.98 $\mathrm{g}, 7.58 \mathrm{mmol}$ ) by the same manner to that described for $3 \mathbf{c}$ : $M_{w} / M_{n}=4,050 / 3,430$ (PDI = 1.18); ${ }^{1} \mathrm{H}$ NMR (DMSO- $d_{6}$, $400 \mathrm{MHz}): \delta 1.89(\mathrm{~m}, 4 \mathrm{H}), 4.84$ (br s, 2H), $5.83(\mathrm{~m}, 2 \mathrm{H})$,
7.13-7.77 (m, 5H); ${ }^{13} \mathrm{C} \mathrm{NMR}\left(\mathrm{CDCl}_{3}, 100 \mathrm{MHz}\right): \delta 19.26$, $128.32,128.50,128.60,129.64,130.13,130.80,132.80 ;{ }^{29} \mathrm{Si}$ $\mathrm{NMR}\left(\mathrm{CDCl}_{3}, 99 \mathrm{MHz}\right): \delta-14.70 ;{ }^{11} \mathrm{~B} \mathrm{NMR}\left(\mathrm{CDCl}_{3}, 160\right.$ $\mathrm{MHz}): \delta-1.24$; IR (KBr, DRIFTS): $v$ 3076, 3059, 2988, 2882, $1692(\mathrm{C}=\mathrm{C}), 1602,1345,1101,759,700,614 \mathrm{~cm}^{-1}$; UV-vis (THF): $\lambda_{\max } \mathrm{nm}(\varepsilon) 254\left(5.71 \times 10^{4}\right)$. Anal. Calcd for $\left(\mathrm{C}_{14} \mathrm{H}_{13} \mathrm{SiBCl}_{2}\right)_{n}$ : C, 57.78; H, 4.50. Found: C, 57.69; H, 4.55 .

A pale yellowish viscous gel 3e (1.3 g, 63\%) was obtained from 1 (1.00 g, $7.58 \mathrm{mmol})$ and butyldichloroborane (2e) $(1.0 \mathrm{M} /$ hexane, $7.58 \mathrm{~mL}, 7.58 \mathrm{mmol})$ by the same manner to that described for 3c: $M_{w} / M_{n}=13,430 / 5,470$ (PDI = 2.45); ${ }^{1} \mathrm{H}$ NMR (THF- $\left.d_{8}, 400 \mathrm{MHz}\right): \delta 0.85-0.91(\mathrm{~m}, 3 \mathrm{H}), 1.28-$ 1.70 (m, 6H), 1.56 (m, 4H), 4.73 (br s, 2H), 5.77 (br s. 2H); ${ }^{13} \mathrm{C} \mathrm{NMR}\left(\mathrm{CDCl}_{3}, 100 \mathrm{MHz}\right): \delta 13.77,18.87,19.43,29.70$, $35.09,128.00,129.40,132.80 ;{ }^{29} \mathrm{Si} \mathrm{NMR}\left(\mathrm{CDCl}_{3}, 99 \mathrm{MHz}\right)$ : $\delta-15.75 ;{ }^{11} \mathrm{~B} \mathrm{NMR}\left(\mathrm{CDCl}_{3}, 160 \mathrm{MHz}\right): \delta-2.25$; IR (neat): $v$ 3031, 2929, 2941, 2862, 2025 (w), 1702 (C=C), 1602, 1370, 1103, 831, $663 \mathrm{~cm}^{-1}$; UV-vis (THF): $\lambda_{\max } \mathrm{nm}(\varepsilon) 269$ $\left(2.24 \times 10^{4}\right)$. Anal. Calcd for $\left(\mathrm{C}_{12} \mathrm{H}_{17} \mathrm{SiBCl}_{2}\right)_{n}: \mathrm{C}, 53.17 ; \mathrm{H}$, 6.32. Found: C, 53.42; H, 6.31 .

Acknowledgment. This work was supported by the Korea Science and Engineering Foundation (Project No. KOSEF R05-2001-000-00192-0) and partly by the Ministry of Commerce, Industry and Energy of the Korean Government. We thank Professor Yong-Rok Kim at Yonsei University, Seoul, Korea for obtaining the electronic spectra of the oligomers and also helpful discussions.

\section{References}

1. Ohshita, J.; Kunai, A. Acta Polym. 1998, 49, 379.

2. (a) Bréfort, J. L.; Corriu, R. J. P.; Gerbier, Ph.; Guérin, C.; Henner, B. J. L.; Jean, A.; Kuhlmann, Th. Garnier, F.; Yassar, A. Organometallics 1992, 11, 2500. (b) Corriu, R. J. P.; Gerbier, Ph.; Guérin, C.; Henner, B.; Fourcade, R. J. Organomet. Chem. 1993, $449,111$.

3. (a) Li, H.; Powell, D. R.; Firman, T. K.; West, R. Macromolecules 1998, 31, 1093. (b) Ohshita, J.; Sumida, T.; Kunai, A.; Adachi, A.; Sakamaki, K.; Okita, K. Macromolecules 2000, 33, 8890.

4. Kwak, Y.-W.; Lee, K.-K.; Cha, S.-H.; Lee, S.-K.; Lee, I.-S.; Park, Y.-T.; Lee, J.; Yoh, S.-D.; Kim, W.-S. Bull. Korean Chem. Soc. 2003, 24, 479.

5. (a) Seo, I. K.; Park, Y. T.; Kim, Y.-R. Bull. Korean Chem. Soc. 1999, 20, 677. (b) Hwang, I.-W.; Song, N. W.; Kim, D.; Park, Y. T.; Kim, Y.-R. J. Polym. Sci., Part B: Polym. Phys. 1999, 37, 2901.

6. (a) Manuel, G.; Weber, W. P.; Boukherroub, R. Main Group Met. Chem. 1996, 19, 263. (b) Brook, M. A. Silicon in Organic, Organometallic, and Polymer Chemistry; John Wiley \& Sons, Inc.: New York, 2000. (c) The Chemistry of Organic Silicon Compounds; Rappoport, Z., Apeloig, Y., Eds.; John Wiley \& Sons: Chichester, UK, 1998; Vol. 2; Patai, S., Rappoport, Z., Eds.; 1989; Vol. 1.

7. Zhang, X.; Zhou, Q.; Weber, W. P.; Horvath, R. F.; Chan, T. H.; Manuel, G. Macromolecules 1988, 21, 1563.

8. Kim, E. J.; Park, J. W.; Kim, Y.-R.; Park, Y. T. Bull. Korean Chem. Soc. 2003, 24, 484.

9. Pelter, A.; Smith, K.; Brown, H. C. Borane Reagents; Academic Press: London, 1988.

10. (a) Chujo, Y.; Tomita, I.; Saegusa, T. Macromolecules 1990, 23, 
687. (b) Chujo, Y.; Tomita, I.; Hashiguchi, Y.; Saegusa, T. Macromolecules 1992, 25, 33.

11. Lee, J. H.; Park, Y. T. Bull. Korean Chem. Soc. 2004, 25, 889.

12. Boukherroub, R.; Manuel, G. J. Organomet. Chem. 1993, 460, 155.

13. Matsumi, N.; Miyata, M.; Chujo, Y. Macromolecules 1999, 32, 4467.

14. Blackborrow, J. R. J. Organomet. Chem. 1977, 128, 161.

15. Odian, G. Principles of Polymerization, 3rd ed.; John Wiley \& Sons: New York, 1991
16. (a) Pretsch, E.; Bühlmann, P.; Affolter, C. Structure Determination of Organic Compounds, Tables of Spectral Data, 3rd ed.; Springer-Verlag: Berlin, 2000. (b) Bellamy, L. J. The Infra-red Spectra of Complex Molecules, 3rd ed.; Chapman and Hall: London, 1975.

17. Matsumi, N.; Kotera, K.; Chujo, Y. Macromolecules 2000, 33, 2801.

18. Barashkov, N. N.; Gunder, O. A. Fluorescent Polymers; Ellis Horwood: New York, 1994.

19. Armarego, W. L. F.; Perrin, D. D. Purification of Laboratory Chemicals, 4th ed.; Butterworth-Heinemann: Oxford, 1996. 